\title{
Thinking Pattern East and West
}

\author{
Adonis Sfera ${ }^{1 *}$ and Carolina Osorio ${ }^{2}$ \\ ${ }^{1}$ Patton State Hospital, State of California, Patton, California, USA \\ ${ }^{2}$ Loma Linda University, Loma Linda, California, USA
}

Received: August 18, 2014; Accepted: August 27, 2014; Published: September 01, 2014

*Corresponding author: Adonis Sfera, Patton State Hospital, State of California, Patton, California, USA, Tel: 714-2672320; E-mail: dr.sfera@gmail.com

In the $13^{\text {th }}$ century, Marco Polo was among the first ones to hint at the fact that the people from the East behave and think differently than the Europeans. The British writer Rudyard Kipling thought that the Eastern and Western mind could not be reconciled [1]. In The Ballad of East and West he wrote:

"Oh, East is East, and West is West, and never the two shall meet,

Till Earth and Sky stand presently at God's great Judgment Seat;"

CG Jung [2] believed that our attitudes and perception of reality were molded by our cultural past. According to him, Asian mind became introverted, collectivist and mystical because throughout its history it avoided the "fatal dissociation between an upper and a lower half of the human personality." In Asian mind the focus of attention was historically directed inward, enabling both a closer contact with the essential nature of life and the development of most religions. The West believes "in doing", Jung stated, while the East in "impassive being". As a consequence of its cultural history the West developed a materialist science which led to the control and exploit of the outer world.

Cultural differences in the way the mind works and processes information may be more important than most people think or imagine, says University of Michigan psychologist, Richard Nisbett [3], author of a recent book "The Geography of Thought: How Asians and Westerners Think Differently...and Why." He states: "When you have a diverse group of people from different cultures, you get not just different beliefs about the world, but different ways of perceiving it and reasoning about it, each with its own strengths and weaknesses."

The fact that geography influenced the history of human civilization is well established, but the idea that it may also change the way we think is less known. Cultural neuroscience, a recent interdisciplinary field, engendered by anthropology, molecular biology and psychology, engendered a treasure trove of data regarding the influence of geography on human mind. It revealed, for instance that Western civilization is focused on the needs of the individual and the process of self-individuation, while Eastern civilization is concerned with the collective needs in which the individual functions as part of a whole.

Like Jung, Richard Nisbett sees the Asian thought as being primarily holistic, less based on formal logic and logical categories than its Western counterpart [3]. By various experiments, Nisbett demonstrated the following differences in information processing between East and West:

1. Westerners are more likely to be interested in an object within a whole, while Asians would focus more on the background that surrounds the object.

2. Westerners usually polarize their beliefs in response to contradiction, while Asians tend to moderate them.

3. When predicting human behavior in response to given situations, Westerners tend to focus on personality characteristics, while Asians are more likely to cite situational factors.

Steven Heine at the University of British Columbia performed similar transcultural studies. He recruited Canadian and Japanese students and he gave them a bogus "creativity" task after which the students were told they had done well in some parts of the task and poorly in others. When a similar test was administered, Canadian students worked harder on the items they were told they had excelled, while the Japanese students insisted more on the areas they thought they did poorly in the first attempt. In other words, the Western students worked on polishing their strength, while the Easterners addressed their weaknesses. The "focused vs. holistic" approach of these students was described by Heine as follows: "if you show an Easterner and a Westerner a photograph and you track their eye movements, you notice something curious. Both subjects fix on some focal point in the picture for about a second. After that, things change. The Westerner continues to gaze at that spot, on that central tree in the forest of possible places to look, while the Eastern eye is all over the place, scanning hither-thither, trying to take in the whole forest" [4].

Japanese cultural psychologist Shinobu Kitayama [5] from the University of Michigan used fMRI to visualize the areas of the brain which activated when Asian-American and Euro-American volunteers tried to draw lines that corresponded proportionally to the sizes of boxes printed on the test paper. People from Japan had a better sense of proportion, while Americans were better at judging the absolute length of the line. They found that on fMRI both groups activate the same areas of the brain, but the task which is more difficult for a particular group required activation 
of additional brain areas. For example, Westerners who had more difficulty getting the ratio of lines to boxes right, activated additional brain areas, while Asians required activation of brain reserves when attempting to reproduce the exact length of the line, which for them was more difficult.

These findings demonstrate that the Western and the Eastern brain are physiologically different and process information in a different manner. Non-routine pattern of thinking in each ethnic group requires mobilization of additional physiological reserves in order to complete the task [6].

Cultural neuroscience seems to indicate that biology and culture shape each other. For example Joan Chiao, PhD from Northwestern University found that people who live in Eastern 'collectivist' cultures may buffer against depression in spite of the fact that they are predisposed to have a form of the serotonin transporter gene, the S-allele that correlates with higher rates of negative effect, anxiety and depression [7].

Demonstrating that information processing differs with ethnicity, cultural neuroscience could usher in an era of greater understanding and tolerance among people from distant geographic regions.

\section{References}

1. Rudyard Kipling's. The Ballad of East and West. Collected Essays. Mercury: London. 1961. p. 189.

2. Jung CG. Psychology and Religion: West and East. Collected Works of CG Jung. 1958. p. 560.

3. Nisbett R. The Geography of Thought: How Asians and Westerners Think Differently - and Why. London: Nicholas Brealey. 2003.

4. Heine S. Zen Ritual: Studies of Zen Buddhist Theory in Practice. In: Steven Heine, Dale Wright, editors. Oxford: Oxford University Press. 2007.

5. Kitayama S, Uskul A. Culture, Mind, and the Brain: Current Evidence and Future Directions. Ann Rev Psychol. 2011; 62: 419-49. doi: 10.1146/annurev-psych-120709-145357.

6. Hedden T, Ketay S, Aron A, Markus HR, Gabri JD. Cultural Influences on Neural Substrates of Attentional Control. Psychol Sci. 2008; 19(1): 12-7. doi: 10.1111/j.1467-9280.2008.02038.x.

7. Chiao JY, Blizinsky KD. Culture-gene coevolution of individualismcollectivism and the serotonin transporter gene. Proc Biol Sci. 2010; 277 (1681): 529-537. doi: 10.1098/rspb.2009.1650. 